HALINA PARAFIANOWICZ (Białystok)

\title{
CZECHOSŁOWACJA I JEJ WIZERUNEK W STANACH ZJEDNOCZONYCH
}

Czechosłowacja była krajem średniej wielkości zarówno pod względem liczby ludności (9 miejsce wśród państw europejskich), jak i terytorium (13 miejsce). Obejmowała obszar $140484 \mathrm{~km} \mathrm{kw.,} \mathrm{z} \mathrm{czego} \mathrm{prawie} \mathrm{połowę} \mathrm{stanowiły} \mathrm{ziemie} \mathrm{właściwych}$ Czech wraz z Morawami, a resztę Słowacja, Ruś Podkarpacka (Zakarpacka), Śląsk Cieszyński i Kraik Hulczyński ${ }^{1}$. Czechosłowacja leżała w centrum Europy, na skrzyżowaniu dróg komunikacyjnych, co stanowiło samo w sobie poważną zaletę.

Po monarchii habsburskiej odziedziczyła Czechosłowacja dwa zupełnie odmienne regiony, z różną przeszłością, inną tradycją, odrębną administracją, a przede wszystkim zróżnicowane pod względem rozwoju gospodarczego. Słowacja i Ruś Podkarpacka, należące przez tysiąc lat do Węgier, były słabo uprzemysłowione i odznaczały się także niską kulturą rolną. Natomiast Czechy i Śląsk Cieszyński, należące przez wieki do Austrii, były znacznie lepiej rozwinięte gospodarczo i urbanizacyjnie (nieprzypadkowo przecież były nazywane „perła” Austrii), co także potwierdzał wyższy dochód narodowy przypadający na statystycznego mieszkańca tych ziem ${ }^{2}$.

Czechosłowacja uzyskała około $21 \%$ terytorium byłej monarchii habsburskiej i $26 \%$ jej ludności. Swój byt niepodległy, choć była podobnie jak inne państwa tego regionu krajem nowym, rozpoczynała wszak po I wojnie światowej w korzystniejszych od nich warunkach gospodarczych. W porównaniu do innych państw sukcesyjnych była ona w znacznie lepszej sytuacji gospodarczej, gdyz odziedziczyła prawie $70 \%$ przemysłu Austro-Węgier. Jeszcze korzystniej to wyglądało dla niektórych dziedzin, gdyz w jej granicach znalazło się $90 \%$ wydobycia węgla byłych Austro-Węgier, $75 \%$ produkcji stali, $80 \%$ przemysłu maszynowego, $80 \%$ artykułów tekstylnych, $92 \%$ przemysłu cukrowniczego, $92 \%$ produkcji szkła itd. Łącznie w przemyśle, transporcie i handlu pracowało blisko $50 \%$ zatrudnionych, a w rolnictwie $38 \%^{3}$.

Czechosłowacja wychodziła z konferencji paryskiej wzmocniona, a jej przyszłość, głównie ze względu na kondycję gospodarczą odziedziczonych ziem, optymistycznie oceniali nawet niedawni jej wrogowie. Był to niewątpliwy sukces czechosłowackiej dyplomacji, dzięki której republika uzyskała granice (z niewielkimi korektami), jakie chcieli Czesi ${ }^{4}$. Nie bez znaczenia był też pozytywny wizerunek młodej republiki 
ukształtowany w tym czasie zarówno w europejskiej, jak i amerykańskiej opinii publicznej ${ }^{5}$. Ten kredyt optymizmu i zaufania okazał się także przydatny Pradze w kolejnych latach.

Polityka Woodrowa Wilsona rozbudziła szczególnie duże nadzieje wśród państw Europy Środkowej i Wschodniej, liczących na większą amerykańską aktywność także po wojnie. Dotyczyło to również Czechosłowacji, która - podobnie jak Polska - podjęła liczne zabiegi, by zaktywizować wzajemne stosunki i skłonić USA do większej aktywności w regionie. Pomoc żywnościowo-surowcowa i zapowiedź powojennej rekonstrukcji „Starego Świata” z udziałem Stanów Zjednoczonych zdawały się potwierdzać, jak sądzono, uzasadnione nadzieje na aktywność USA na gruncie europejskim.

USA, mimo swoistego „zaniedbywania” Europy Środkowej, były jednak zainteresowane jej stabilizacja gospodarczo-polityczna. Naturalnie Waszyngton dużo większą uwagę skupiał na położeniu Niemiec, odbudowę których traktował jako warunek stabilizacji międzynarodowej gospodarki oraz, z drugiej strony, na Rosji, która przez kilka lat była swoistym straszakiem komunistycznym dla całego świata.

Politycy czescy zdawali sobie z tego doskonale sprawę, tym bardziej więc wykorzystywali atuty swego kraju, docierając ze swoją argumentacją do Amerykanów. Akcentowali oni głównie dwie sprawy, a więc sukces gospodarczo-polityczny młodej demokracji (uprzemysłowienie kraju i prosperity; „Praga jako Mekka demokracji") oraz jej aktywny udział w pokojowej rekonstrukcji powojennej Europy Środkowej (Edvard Beneš - inicjator i twórca Małej Ententy; „Praga - centrum słowiaństwa" ${ }^{6}$. Co więcej, jak twierdził Beneš i jego ekipa, Praga była nie tylko ważnym, ale i niezbędnym elementem powojennej rekonstrukcji gospodarczo-politycznej regionu. Musimy pamiętać, że był to zarazem kontrargument dla lansowanej przez propagandzistów niemieckich tezy o „sezonowości” tych państw i rozwiązań powojennych w Europie Środkowej.

W Departamencie Stanu i kręgach establishmentu amerykańskiego sporo uwagi poświęcano w tym czasie komunizmowi i groźbie jego rozprzestrzenienia się. Liczne dyskusje w kręgach rządowych na temat Europy Środkowej i Wschodniej - w tym toczącej się wojny polsko-radzieckiej - wydawały się potwierdzać żywe zainteresowanie USA losami regionu. I w tym kontekście zwłaszcza, i zresztą na krótko, niektóre kraje stawały się tam obiektem rosnącego zainteresowania. Czechosłowacja, Węgry i Austria, a zwłaszcza Polska, właśnie ze względu na swoje położenie geopolityczne pomiędzy pokonanymi Niemcami i rewolucyjna Rosją, budziły większe zainteresowanie nie tylko kręgów politycznych europejskich, ale i amerykańskich.

Praga przywiązywała dużą rolę do propagandy zagranicznej i czynniki oficjalne od początku podjęły kroki w tym względzie. Zapoczątkowane przez MSZ w trakcie obrad paryskich popieranie i finansowanie poczynań propagandzistów czeskich i słowackich z USA kontynuowano w kolejnych latach na większą skalę. Wspierano nieraz, także finansowo, działalność organizacji i stowarzyszeń czechosłowacko-amerykańskich, ich akcje odczytowe i wizyty gości z Czechosłowacji. Wykorzystywano 
do tego działaczy emigracyjnych, lokalną prasę i periodyki. Ukazujący się w Chicago od listopada 1918 roku „The Czechoslovak Review” (CzR) poświęcał wiele uwagi polityce wewnętrznej i zagranicznej Czechosłowacji, a zwłaszcza kontaktom z USA. Miesięcznik ten okazał się na gruncie amerykańskim bardzo przydatny w akcji popularyzacyjno-propagandowej młodej republiki. Także do wizyt Amerykanów w Czechosłowacji przywiązywano dużą wagę, organizując ich pobyty i należytą oprawę. Spotkania i audiencje u prezydenta Masaryka służyły również popularyzacji kraju. Po powrocie do USA goście bowiem chętnie wypowiadali się na temat swoich wizyt i spotkań w Czechosłowacji, także jej kondycji gospodarczo-politycznej ${ }^{7}$.

W USA coraz częściej pojawiały się wzmianki o Czechosłowacji, jej polityce wewnętrznej i zagranicznej oraz dokonaniach młodej demokracji. Pisano o sukcesach republiki i jej twórców, którzy potrafili umiejętnie wykorzystać sytuację i pokierować należycie odbudowa państwa ${ }^{8}$.

Nowo powstałe kraje, w tym i Czechosłowacja, cieszyły się po I wojnie światowej wzrastającym zainteresowaniem różnych amerykańskich środowisk. Ożywione kontakty nawiązywali z nimi Amerykanie, których rodziny pochodziły z tego regionu, także biznesmeni i środowiska uniwersyteckie. Należy pamiętać, że wizyty Amerykanów w krajach środkowoeuropejskich nie były w tym czasie rzadkością. W 1919 i na początku lat dwudziestych odwiedzali oni często kraje tego regionu. I to nie tylko jako przedstawiciele firm prywatnych, ale i członkowie delegacji rządowych. Amerykańscy goście objeżdżali przede wszystkim stolice tych państw, a więc Pragę, Wiedeń, Budapeszt, także Warszawę. Czasem ich trasa wiodła do Belgradu albo nawet do Moskwy, a prawie zawsze w jej ramach był Berlin. Wizyty te stały się także znakomita formą popularyzacji krajów regionu, w tym Czechosłowacji.

Wizyty amerykańskich polityków i działaczy gospodarczych oraz przedstawicieli środowisk naukowych (m.in. płk. Edwarda M. House'a, Franka Vanderlipa, Nicholasa M. Butlera) w krajach środkowoeuropejskich, w tym i Czechosłowacji, budziły tam zrozumiałe zainteresowanie ${ }^{9}$. Czesi starali się również wykorzystać swoich gości do celów propagandowych. Cudzoziemcy wizytujący kraj dzielili się potem wrażeniami z pobytu w Czechosłowacji. Szczególnie użyteczne były opinie osób publicznych, zwłaszcza z kręgów rządowych, wypowiadających swoje zdanie na temat kondycji odwiedzanego państwa, jego sytuacji finansowej, źródeł surowcowych, polityki zagranicznej etc. Publikowane zaś materiały z konferencji czy raporty polityków i rozmaitych ekspertów wizytujących państwa sukcesyjne miały dużą wartość informacyjną na gruncie amerykańskim.

Działalność YMCA, YWCA, Czerwonego Krzyża i rozmaitych organizacji charytatywnych, a zwłaszcza American Relief Administration (ARA), odegrały ważną rolę - podobnie jak w innych krajach regionu - w odbudowie powojennej Czechosłowacji. ARA jako agencja pomocy i rekonstrukcji „Starego Świata” organizowała dostawy żywnościowe, odzieżowe i medyczne państwom najdotkliwiej poszkodowanym w czasie I wojny światowej. Stała się ważnym elementem w powojennej amery- 
kańskiej polityce. Jej działacze odegrali też dużą rolę w popularyzacji spraw Europy Środkowej w amerykańskiej opinii publicznej. Z sympatią wypowiadali się nieraz o Czechosłowacji i jej mieszkańcach oraz szanowanym tam powszechnie prezydencie Tomášu G. Masaryku. Anson Conger Goodyear wskazywał, że Czesi są dobrymi biznesmenami i fachowcami, że kraj może być samowystarczalny i przyczyniać się do stopniowej stabilizacji regionu ${ }^{10}$. Tego typu opinie docierały do szerokich kręgów społeczeństwa amerykańskiego, często też były cytowane w prasie. Miało to duży wpływ na wizerunek Czechosłowacji, który w przyszłości stał się elementem bardzo użytecznym dla celów politycznych.

Na łamach „New York Times” gościły często wzmianki, komentarze i artykuły o Czechosłowacji. Frank Dilnot w czerwcu 1920 w korespondencji z Pragi pisał o rozmowie z nowym premierem, Vlastimilem Tusarem, który wyraził nadzieję na amerykańskie poparcie dla młodej republiki. Czeski polityk podkreślał, że ta pomoc może przyjść w postaci dostaw niezbędnych surowców dla przemysłu Czechosłowacji, a z drugiej strony poprzez zakup nadwyżki czeskich towarów przemysłowych. Dodał też, że kraj oczekuje życzliwej polityki finansowej ze strony USA, dzięki czemu Bohemia spełni wszystkie warunki, by „stać się europejską Kalifornią"11. W przyszłośçi właśnie szczególnie prosperity i sukcesy gospodarcze młodej republiki cieszyły się dużym uznaniem Amerykanów.

Wypowiedzi kuratora Muzeum Narodowego w Waszyngtonie Aleša Hrdlički ${ }^{12}$ i Charlesa H. Grasty dawały bardzo korzystny obraz Czechosłowacji. Ten ostatni pisał, że kraj posiadał nie tylko najlepiej uprzemysłowioną część dawnej monarchii Habsburgów, ale i „szczególnych ludzi ze względu na swoją duchowość i energię”. To sa „Jankesi Europy Środkowej”, jak zapewniał Grasty. Cechuje ich realizm i pragmatyzm. Dla obrony własnej niezawisłości Czesi, choć nie mają skłonności do militaryzmu, stworzyli - pod okiem Francuzów - znakomitą i dobrze wyszkoloną armię ${ }^{13}$.

Także córka Masaryka, Alice, popularyzowała Czechosłowację na gruncie amerykańskim. W 1921 odwiedzała ośrodki czeskie i słowackie w USA, zajmując się akcja dobroczynną i propagowaniem rodzimej sztuki ludowej ${ }^{14}$.

Warto też pamiętać, że akcja popularyzacyjno-propagandowa Czechosłowacji za granica, a zwłaszcza podkreślanie jej osiągnięć gospodarczych i kreowanie w ten sposób pozytywnego image'u kraju, odegrały bardzo użyteczną rolę. Anglojęzyczne broszurki i opracowania ${ }^{15}$, inspirowane i finansowane w duzej mierze przez czeskie czynniki oficjalne, odegrały już wtedy ważną i użyteczną rolę propagandową. Bardzo pomocne w tym względzie okazały się opracowania attaché prasowego w Wielkiej Brytanii i USA, Alexandra Broža, które popularyzowały osiągnięcia nowego państwa zarówno w polityce wewnętrznej, jak i zagranicznej ${ }^{16}$.

W USA w tym czasie podejmowano liczne inicjatywy, by przybliżyć Europę Środkową i jej poszczególne kraje Ameryce i vice versa. Uniwersytety i ośrodki badawcze organizowały rozmaite konferencje, zebrania i odczyty, informując w ten sposób Amerykanów o sytuacji w regionie. Uczestniczyli w nich także politycy, 
a częstym tematem dyskusji był udział USA w tworzeniu międzynarodowego ładu i zachowaniu pokoju w świecie ${ }^{17}$.

Rozpad Austro-Węgier automatycznie zmniejszył znaczenie i rolę Wiednia, co chciała zdyskontować Praga, pretendując do spełniania podobnej funkcji, jaką wcześniej pełniła stolica Habsburgów. Czesi niejednokrotnie zapewniali, że w bliskiej przyszłości Praga przejmie wcześniejszą funkcję Wiednia, stając się właściwym centrum gospodarczo-politycznym i kulturalnym regionu. Poważnym konkurentem w tym względzie okazała się przede wszystkim Warszawa, którą wielu polityków polskich oraz dyplomaci zagraniczni tam rezydujacy widzieli jako główne centrum informacyjne o Europie Środkowej i Wschodniej ${ }^{18}$. Ponadto, jak nieraz publicznie zapewniali Czesi, Czechosłowacja była skuteczną bariera przeciwko ekspansji komunizmu ${ }^{19}$. Jej kondycja gospodarcza i położenie geograficzne pomiędzy Rosja a Niemcami okazały się użytecznym walorem politycznym, co Czesi potrafili wykorzystać także na gruncie amerykańskim.

Wydaje się, że Praga odniosła początkowo znaczny sukces w prowadzeniu własnej polityki i kreowaniu swojej roli w Europie Środkowej. Mając życzliwe poparcie sojuszniczej Francji, Czesi starali się pozyskać także Wielką Brytanię oraz Stany Zjednoczone, z którymi wiązali znaczne nadzieje. Do stosunków z USA, zwłaszcza na początku, przywiązywano w Pradze dużą wagę, doskonale sobie zdając sprawą ze znaczenia ich mocarstwowej polityki. Amerykański udział w konferencji paryskiej i wpływ na jej decyzje potwierdził aktywną i wzrastającą rolę USA w stosunkach międzynarodowych, z czego politycy czescy wyciągnęli wnioski. W kolejnych latach starali się więc o zainteresowanie, życzliwość i poparcie Amerykanów dla odbudowującej się republiki.

Od początku Praga bardzo dbała także o należytą informację i właściwą reklamę czeskich produktów. W różnych wypowiedziach i instrukcjach handlowych działacze gospodarczy niejednokrotnie podkreślali, że dla rodzimych towarów należy jak najszybciej stare etykietki „Made in Austria” zastąpić nowymi - „Made in Czechoslovakia" ${ }^{20}$. Nie było to bez znaczenia i bynajmniej nie tylko o symbolikę chodziło. Przypominano w ten sposób światowej opinii publicznej, że rozpad monarchii Habsburgów stał się rzeczywistością. Towary czeskie, posiadające dobrą markę i przez lata utożsamiane z austriackimi (bo pochodziły z ówczesnej Austrii), miały teraz propagować rodzimy przemysł i świadczyć o sukcesie odradzającej się Czechosłowacji.

Dla promocji własnego przemysłu Czesi zainicjowali, wzorując się na Lyonie i Lipsku, międzynarodowe targi przemysłowo-handlowe, Prague Fairs. Pierwsze z nich miały miejsce we wrześniu 1920, a potem w kolejnych latach odbywały się one dwa razy w roku, jesienią i wiosną ${ }^{21}$. Targi te, zdobywające $\mathrm{z}$ czasem coraz większą popularność, były świetną reklamówką przede wszystkim Czechosłowacji i jej możliwości gospodarczych. Przyczyniły się w dużej mierze do ożywienia wymiany handlowej także ze Stanami Zjednoczonymi.

Waszyngton przywiązywał znaczną wagę do pracy poselstwa USA w Pradze, 
zwłaszcza w latach 1919-1920, kiedy wielu Amerykanów w Czechosłowacji widziało „najważniejszą barierę ochronną dla cywilizacji zachodniej”. Czesi, ich zdaniem, mogli odegrać doniosłą rolę w „spychaniu zagrożenia bolszewickiego, tak bardzo groźnego dla całej Europy" 22 . W latach powojennych podobną rolę wyznaczano również Polsce, zwłaszcza w obliczu inwazji bolszewickiej w 1920 roku, a każdy $\mathrm{z}$ tych krajów, choć z różnym skutkiem, próbował to zdyskontować.

Poselstwo USA w Pradze początkowo traktowano w Departamencie Stanu jako ośrodek ważnej informacji nie tylko o Czechosłowacji, ale w ogóle o Europie Środkowej i Wschodniej. Podobną rolę wyznaczano także innym placówkom dyplomatycznym USA w stolicach państw środkowoeuropejskich, starając się w ten sposób uzyskać w miarę pełny obraz położenia regionu. Niestabilność sytuacji na tym obszarze, a zwłaszcza wydarzenia w Rosji, rewolucja na Węgrzech, także wojna polsko-radziecka automatycznie niejako czyniły z Pragi potencjalny punkt informacyjny o tych wydarzeniach.

Politycy czescy kreowali z kolei Czechosłowację jako ostoję „ładu, pokoju i stabilizacji” w regionie i usiłowali wykorzystać położenie geograficzne kraju. Po dezintegracji Austro-Węgier i ogólnej destabilizacji gospodarczo-politycznej Europy Środkowej miało to swoją wymowę. Alianci widzieli (bo chcieli widzieć, zresztą nie bez usilnych zabiegów Czechów) Pragę jako „przyczółek zachodniej cywilizacji”, a ich placówki dyplomatyczne „obsługiwały” początkowo w dużym stopniu również pokonaną Austrię i rewolucyjne Węgry. Ponadto Czesi stale podkreślali, że ważnym atutem był już sam fakt, że Czechosłowacja leżała pomiędzy Rosją a Niemcami. Mogła więc służyć jako pomost między Wschodem i Zachodem, słowiańszczyzną i światem germańskim. Wskazywali, że także dla Amerykanów Czechosłowacja mogła być właściwym pomostem do Rosji, zwłaszcza w sprawach handlowych.

Praga konsekwentnie przedstawiała światu swój kraj jako harmonijnie funkcjonująca republikę czechosłowacką, choć od początku - ze względu na separatyzm słowacki - był to poważny problem. Oficjalny czechosłowakizm Pragi usilnie propagowano także na gruncie amerykańskim, gdzie liczebna i aktywna kolonia słowacka demonstrowała nieraz swoją odrębność narodową. Politycy czescy dyskretnie też wypowiadali się na temat położenia ponad 3-milionowej mniejszości niemieckiej oraz 760 tys. Węgrów, którym - jak zapewniali - gwarantowano pełne prawa obywatelskie. Beneš i Masaryk, zwłaszcza w wypowiedziach prasowych, określali Czechosłowację jako „rodzaj Szwajcarii”.

Czesi przywiązywali dużą wagę do pracy amerykańskiego poselstwa w Pradze. Może poniekąd była to również sprawa taktyki, ale niewątpliwie Pradze, zwłaszcza na początku, bardzo zależało na pozyskaniu USA do aktywniejszych działań na gruncie środkowoeuropejskim. Także i dlatego żywo interesowano się obsada personalną amerykańskiego poselstwa w Pradze. Czesi okazali się dosyć skuteczni w zabiegach, by na tamtejszą placówkę przysyłano życzliwych im ludzi, czasem pochodzenia czeskiego. Umieli też - co potwierdzała praktyka - ich sympatię zdobywać. W poselstwie, konsulacie i ataszacie wojskowym USA w Pradze, zwłaszcza 
na początku, niektórzy pracownicy byli Amerykanami pochodzenia czeskiego. Ich znajomość języka czeskiego, obyczajów i realiów w kraju urzędowania okazywała się użyteczna. Pomocnikiem attaché wojskowego był kpt. Frank Jehlička, wysłannikiem rządowym ds. handlowych Vladimir A. Geringer, a sekretarzem poselstwa był krótko Louis Jalovec ${ }^{23}$.

Pierwszym amerykańskim posłem w Czechosłowacji został Richard Crane, dotychczasowy sekretarz Roberta Lansinga, sekretarza stanu. Był on, podobnie jak jego ojciec Charles, znany biznesmen i filantrop, sympatykiem Czechów i Słowaków oraz tworzonego przez nich państwa ${ }^{24}$.

Crane miał liczne kontakty w praskich kręgach rządowych, które mogły być użyteczne, jak powszechnie sądzono, w Waszyngtonie, w jego pracy dyplomatycznej. Życzliwość amerykańskiego posła dla kraju swego urzędowania oraz bliskie kontakty $\mathrm{z}$ rodziną Masaryka dawały mu także specjalne miejsce $\mathrm{w}$ miejscowej elicie towarzyskiej ${ }^{25}$.

Dzięki tym koneksjom poseł amerykański miał łatwy dostęp do informacji o sytuacji gospodarczo-politycznej kraju, choć nie wydaje się, by umiał to należycie wykorzystać. Przysyłał on obszerne raporty do Waszyngtonu o polityce wewnętrznej i zagranicznej Czechosłowacji, cytując nader często Beneša i prasę czeską. Przekazywane zaś przez Czechów informacje zazwyczaj brał dosłownie, bez żadnego dystansu i krytycyzmu, co z czasem budziło wzrastające niezadowolenie w Waszyngtonie. W Pradze zaś amerykański poseł uchodził wtedy i potem za „szczerego i oddanego przyjaciela" Czechosłowacji, a jego praca spotykała się z uznaniem i wdzięcznością czynników oficjalnych ${ }^{26}$.

Ale z upływem czasu aktywność dyplomatyczna Crane'a nie spotykała się z podobnie wysoką oceną w Departamencie Stanu. Wręcz odwrotnie, specjalista do spraw europejskich z Wydziału Europy Zachodniej, późniejszy jego szef, William R. Castle coraz sceptyczniej odnosił się do poczynań posła w Pradze, a zwłaszcza do jego zbyt bezkrytycznych i apologetycznych raportów o Czechosłowacji. Budziły one coraz większe zniecierpliwienie i krytycyzm Castle'a, który w jednym z listów do posła USA w Polsce, Hugha S. Gibsona, z 9 grudnia 1920 pisał wręcz, że potrzebuje konkretnych informacji na temat położenia Czechosłowacji, a nie propagandy na jej temat. Ironicznie zauważył, że opierając się na raportach Crane’a już niebawem w Departamencie zapanuje przekonanie, że jest to „cudowny kraj i najlepszy wzorzec szlachetności, demokracji i postępu w całym świecie" ${ }^{27}$. Tak więc raporty dyplomatyczne Crane'a, niekwestionowanego sympatyka Czechosłowacji, miały z czasem niewielki rezonans w Departamencie Stanu, gdyż straciły wiarygodność. W ten sposób Crane osłabił nie tylko własną pozycję, ale i obniżył rangę poselstwa USA w Pradze. Powstała wręcz paradoksalna sytuacja, gdyż częste i obszerne raporty posła, regularnie informujące o różnych aspektach polityki Czechosłowacji, nie znajdowały większego zainteresowania, ani tym bardziej uznania w Departamencie Stanu, gdyż straciły na wiarygodności. Natomiast wywiady i komentarze prasowe posła o polepszającej się sytuacji Czechosłowacji i jej poko- 
jowych wysiłkach żyły własnym życiem i odegrały użyteczną rolę propagandową na terenie Stanów Zjednoczonych. Tego typu wzmianki w prasie amerykańskiej przyczyniły się w znacznym stopniu do kśztałtowania i ugruntowania pozytywnego image'u Czechosłowacji.

Do pracy attaché wojskowego płk. Wernera E. R. McCabe przywiązywano w Waszyngtonie znaczniejszą wagę, a w każdym bądź razie raporty jego studiowano uważnie nie tylko w Departamencie Wojny. Były one chyba bardziej opiniotwórcze niż raporty Crane'a i w pewnym sensie poszerzały informacje przesyłane przez posła z Pragi. Charakterystyczne jest, że podobnie jak inni przedstawiciele dyplomatyczni i konsularni, również amerykański attaché wojskowy w Pradze w raportach do Waszyngtonu szczególnie wiele uwagi poświęcał sytuacji ekonomicznej Czechosłowacji. A ta, ich zdaniem, była dobra i wciąż się polepszała, co było dla Amerykanów zachętą do współpracy. Nieraz pisano też o prezydencie Masaryku i jego „rozważnej polityce", dzięki której kraj ten - w odróżnieniu od innych państw regionu - uniknął straszliwych zniszczeń. Wielokrotnie podkreślano, że w 1920 Czechosłowacji nie groziła anarchia ani komunizm ${ }^{28}$. Podobne komentarze pojawiały się nieraz w raportach amerykańskich przedstawicieli dyplomatycznych i konsularnych z Pragi. To z kolei utwierdzało Amerykanów z establishmentu w przeświadczeniu, że sytuacja gospodarczo-polityczna Czechosłowacji i jej postępująca stabilizacja są dobrym prognostykiem dla stosunków wzajemnych. Budziło to zainteresowanie, życzliwość i zaufanie wielu Amerykanów do nowego państwa, co w konsekwencji wpływało na inicjatywy gospodarcze.

McCabe w jednym z raportów z 26 kwietnia 1921 wskazał na duże znaczenie kierowanej przez siebie placówki. Wynikało to, jak podkreślał, już z samego faktu, że Czechosłowacja leżała w centrum Europy, a otoczona była przez kraje wrogie i nieprzyjazne. Tu przebiegał odwieczny konflikt teutońsko-słowiański, który nadal dawał o sobie znać. Silne wpływy francuskie w Czechosłowacji po I wojnie światowej miały, co potwierdzał McCabe, wyraźne ostrze antyniemieckie. Jego zdaniem Czechosłowacja wprawdzie nigdy nie będzie ważnym ogniwem wojskowym na kontynencie, ale ze względu na potencjał ekonomiczny może odegrać aktywną rolę w europejskich stosunkach gospodarczych. Ponadto była ona ważnym czynnikiem w polityce środkowoeuropejskiej, zwłaszcza jako inicjator i twórca Małej Ententy, a zarazem naturalny korytarz do Rosji. Kontekst rosyjski attaché szczególnie akcentował także i dlatego, że w Czechosłowacji stacjonowały misje Aleksandra Kiereńskiego oraz aktywiści ukraińscy ${ }^{29}$. Jak widać w raporcie tym znalazły się kwestie często podnoszone również przez innych przedstawicieli dyplomatycznych i konsularnych USA, którzy wskazywali na miejsce Czechosłowacji w nowym układzie sił w Europie. Kontekst rosyjski i niemiecki, na co szczególną uwagę zwracali sami Czesi, nadawał ważności Czechosłowacji, zwłaszcza w środkowoeuropejskiej polityce.

26 października 1921 Crane uczestniczył w pożegnalnym spotkaniu korpusu dyplomatycznego, na którym bardzo ciepło wypowiedział się na temat kraju, który 
opuszczał. Czuł się zaszczycony, że był pierwszym amerykańskim posłem w tym kraju, którego przyszłość, co podkreślał, rysowała się pomyślnie. Był on - jak twierdził - naocznym świadkiem jego szybkiej odbudowy i rozwoju stosunków amerykańşko-czechosłowackich. $\mathrm{Na}$ koniec Crane wyraził przekonanie, że Czechosłowacja była „przeznaczona do odegrania doniosłej roli w rekonstrukcji i dalszej konsolidacji Europy Środkowej" ${ }^{30}$. W dwa dni potem, w trakcie specjalnej audiencji prezydent Masaryk serdecznie podziękował Crane'owi za życzliwość i sympatię okazywaną Czechosłowacji, które były - jak podkreślił - bardzo potrzebne młodej republice ${ }^{31}$. W kolejnych latach Crane podtrzymywał serdeczne stosunki z czeskimi przyjaciółmi, odwiedzał Pragę i prezydenta Masaryka. Wypowiadał się równie życzliwie jak uprzednio na temat Czechosłowacji i jej sukcesów ${ }^{32}$.

W rozwoju stosunków amerykańsko-czechosłowackich ważną rolę odegrało również poselstwo Czechosłowacji w Waszyngtonie, które uchodziło za placówkę ważną i prestiżową. Do jego pracy politycy czescy przywiązywali dużą wagę, zwłaszcza na początku, kiedy Praga liczyła na ożywioną współpracę z Ameryką. Było ono aktywne w propagowaniu, w różny zresztą sposób, kraju i jego polityki. Charles Pergler jako specjalny wysłannik, a potem kolejni przedstawiciele dyplomatyczni Czechosłowacji w USA, zwłaszcza Jan Masaryk i Bedřich Štěpánek, usilnie zabiegali nie tylko o amerykańskie poparcie dla nowego państwa i jego granic, ale przede wszystkim o amerykańskie kredyty i zacieśnienie kontaktów bilateralnych. Popularyzowali także Czechosłowację i jej sukcesy szerokim kręgom amerykańskiej opinii publicznej ${ }^{33}$.

Pergler odegrał ważną rolę w aktywizacji kół czeskich i słowackich w USA. Brał on udział w rozlicznych spotkaniach rodaków, ale też często zabierał głos publicznie, adresujac swoje wypowiedzi do Amerykanów. Informował ich w ten sposób o problemach Czechosłowacji, popularyzując zarazem nowe państwo amerykańskiej publiczności. Odbywał też tury odczytowe o Czechosłowacji i jej położeniu gospodarczym, udając się do większych skupisk czeskich, m.in. Omaha (Nebraska), Des Moines i Cedar Rapids (Iowa) ${ }^{34}$.

2 sierpnia 1919, kiedy Pergler wyjeżdżał z USA, kończąc swoją misję specjalnego wysłannika Czechosłowacji, jego pracę oceniano w Pradze wysoko. Wskazywano przede wszystkim na użyteczność działalności popularyzatorskiej i propagandowej, którą rozwijał. Liczne artykuły, pamflety i odczyty zapoznawały na bieżąco amerykańską opinię publiczna z sytuacją Czechosłowacji. Pergler też odegrał aktywną rolę w pozyskaniu amerykańskich kredytów ${ }^{35}$.

Również Jan Masaryk, wykorzystując rozliczne kontakty osobiste, popularyzował problematykę kraju na gruncie amerykańskim ${ }^{36}$. Po jego przeniesieniu do Londynu i krótkim urzędowaniu Karela Hally jako chargé d'affaires, posłem w Waszyngtonie został Bedřich Štěpánek, który bardzo energicznie rozpoczął urzędowanie. Natychmiast po przybyciu do Nowego Jorku udzielił on wywiadu, wskazując na postępującą stabilizację kraju i stopniową jego unifikację. Podkreślił, że sytuacja gospodarcza Czechosłowacji była znacznie lepsza niż innych państw tego regionu. 
Ponadto, jak zapewniał, krajowi nie zagrażała „infekcja komunizmu”, co wciąż było realnym zagrożeniem dla innych państw środkowoeuropejskich ${ }^{37}$.

Štěpánek był aktywny w popularyzowaniu spraw Czechosłowacji w USA, ściśle współpracując z amerykańskimi Słowakami i Czechami oraz rozmaitymi stowarzyszeniami popierającymi współpracę z Europą Środkową. W kwietniu 1921, w trakcie uroczystych obchodów rocznicy Jana Amosa Komeńskiego poseł był głównym mówcą na spotkaniu z udziałem m.in. slawistów żywo zainteresowanych rozwojem kontaktów USA z krajami środkowoeuropejskimi ${ }^{38}$. Była to kolejna okazja do popularyzacji Czechosłowacji i jej spraw na gruncie amerykańskim.

Praga przywiązywała także dużą rolę do pracy swoich placówek konsularnych w USA, którym wyznaczano ambitne plany poszerzania kontaktów wzajemnych. Początkowo funkcjonowało tam 5 konsulatów, które znajdowały się w największych skupiskach czeskich i słowackich. W 1921 konsulaty istniały w Chicago, Omaha, Nowym Jorku, Cleveland i Pittsburghu ${ }^{39}$. W kolejnych latach powołano dalsze konsulaty, m.in. w Los Angeles, Kansas, Galveston, Seattle, San Francisco, Saint Louis, Minneapolis ${ }^{40}$. Rozbudowana sieć konsularna zaspokajała także wzrastające potrzeby skupisk emigracyjnych i przede wszystkim umożliwiała prowadzenie rozległej akcji informacyjno-popularyzacyjnej o Czechosłowacji. Ich rozbudowa i stawiane przed nimi nowe zadania związane były w głównej mierze z próbami przeciwdziałania propagandzie węgierskiej na terenie USA ${ }^{41}$.

Ograniczone możliwości kadrowe i finansowe poselstwa Czechosłowacji w USA oraz jej konsulatów utrudniały podjęcie szerszych działań w tym względzie. W tym celu powołano przy konsulacie Biuro Prasowe, kierowane przez Milana Gettinga. Zajmowało się ono propagandą prasową na gruncie amerykańskim oraz odpowiedzialne było za raporty prasowe o sytuacji USA $^{42}$.

Aktywną rolę $\mathrm{w}$ nawiązywaniu kontaktów $\mathrm{z}$ państwami środkowoeuropejskimi odegrało American Mid-European Association i jego przedstawiciele, a zwłaszcza przewodniczący, znany biznesmen i pracownik Departamentu Pracy, Robert J. Caldwell. Współpracował on $\mathrm{z}$ wieloma osobistościami politycznymi Europy Środkowej, m.in. z prezydentem Masarykiem. W pracy stowarzyszenia udział brali m.in. Nicholas Murray Butler, Sidney E. Mezes, Henry Morgenthau ${ }^{43}$.

Politycy czescy przywiązywali znaczną wagę do inicjatyw stowarzyszenia, z którym współpracowali w nawiązywaniu kontaktów gospodarczych USA z Czechosłowacją. Na początku swojej działalności w latach 1919-1921 stowarzyszenie przyczyniło się w znacznej mierze do popularyzacji spraw środkowoeuropejskich, a zwłaszcza czechosłowackich, na gruncie amerykańskim.

Caldwell ułatwiał rodakom kontakty z Czechami i rekomendował wielu Amerykanów, m.in. rzecznika Ligi Narodów i współpracy ze „Starym Światem”, Hamiltona Holta z „Independence”, który wybierał się z wizytą do Pragi. Informował té prezydenta Masaryka o poczynaniach stowarzyszenia i dobrym wizerunku Czechosłowacji w amerykańskich mass mediach ${ }^{44}$, do czego równiez przyczyniał się swoja działalnością. 
Latem 1920 Caldwell złożył wizytę w Czechosłowacji, w trakcie której podkreślał potrzebę zacieśniania współpracy z krajami Europy Środkowej. W wypowiedziach i końcowym raporcie, niedługo potem opublikowanym przez wydawnictwo rządowe USA, przedstawił on pozytywny wizerunek młodej republiki. W pracy obszernie cytowano wypowiedzi ministrów i działaczy gospodarczych Czechosłowacji, które świadczyły o polepszającej się kondycji państwa ${ }^{45}$. Była to nie tylko dobra wizytówka nowego kraju, niezbyt przeciez znanego w świecie, ale zarazem oferta i zachęta do współpracy. Czesi zdawali sobie sprawę z użyteczności takich poczynań i nieprzypadkowo zabiegali, by w raporcie Caldwella znalazły się dane i informacje o postępie i rozwoju różnych dziedzin gospodarki Czechosłowacji.

Odbudowujące się powoli kraje środkowoeuropejskie, w tym zwłaszcza przodująca w rozwoju gospodarczym Czechosłowacja, przestawały być postrzegane, jak to przedstawiała propaganda rewizjonistyczna, jako element tymczasowy i destabilizujący. Czechosłowacja, dzięki szybkiej odbudowie gospodarczej i powojennej prosperity, stała się obiektem życzliwego zainteresowania amerykańskich kół przemysłowych, o czym świadczyła też wymiana handlowa w tym czasie.

Politycy czescy, podobnie jak polscy, liczyli na aktywność USA w sprawach europejskich, podkreślając niejednokrotnie ich wagę nie tylko dla stosunków bilateralnych, ale i współpracy międzynarodowej. W Pradze zdawano sobie doskonale sprawę z nierównorzędności pozycji Czechosłowacji i USA we wzajemnych stosunkach. Czesi starali się - podobnie jak to czyniły inne małe kraje - dostosować politykę do wymogów polityki amerykańskiej, lansując przy tym własną wizję miejsca i roli Czechosłowacji w Europie Środkowej. Wydaje się, że odnieśli na tym polu spore sukcesy.

Poselstwo i konsulaty Czechosłowacji w USA, a zwłaszcza niektórzy ich przedstawiciele, odegrali ważną rolę w akcji informacyjno-propagandowej młodego kraju za Oceanem i w rozwoju stosunków bilateralnych. Także kręgi gospodarczo-finansowe i uniwersyteckie obu krajów oraz amerykańscy Czesi i Słowacy mieli w tym swój aktywny udział, zwłaszcza w popularyzacji Czechosłowacji i wykreowaniu jej pozytywnego wizerunku.

O ile w trakcie obrad paryskich Czechosłowacja była „ukochanym dzieckiem aliantów", to w opinii publicznej za granica, zwłaszcza w USA, juz w pierwszych latach niepodległego bytu uchodziła za kraj prosperujący oraz ważny i stabilny element w polityce środkowoeuropejskiej ${ }^{46}$.

W prasie amerykańskiej nierzadko pisano o Czechosłowacji jako o kraju „ładu i prosperity” i jej mieszkańcach, „Jankesach Europy Środkowej”. W kolejnych latach przeświadczenie to zostało ugruntowane, a jej „ojcowie założyciele” - Masaryk i Beneš i ich polityka cieszyły się również uznaniem i życzliwością Amerykanów ${ }^{47}$. Był to niewatpliwy sukces Czechosłowacji, nie tylko propagandowy. Ten pozytywny wizerunek i życzliwy dla niej klimat zręcznie wykorzystano w kolejnych latach także dla celów politycznych. 


\section{PRZYPISY}

1. Statistická příručka československé republiky, Praha 1937, s. 5. Czechosłowacja graniczyła z Niemcami $(1550 \mathrm{~km})$, Polską $(984 \mathrm{~km})$, Węgrami $(832 \mathrm{~km})$, Austrią $(558 \mathrm{~km})$ i Rumunia $(201 \mathrm{~km})$.

2. Z. P. Pryor, Czechoslovak Economic Development in the Interwar Period, [w:] V. Mamatey, R. Luža, eds., A History of the Czechoslovak Republic, 1918-1948, Princeton 1973, s. 190.

3. C. A. MaCartney, A. W. Palmer, Independent Eastern Europe, 1918-1941. A History, London 1962, s. 156-159; A. Teichova, An Economic Background to Munich. International Business and Czechoslovakia 1918-1938, Cambridge University Press 1974, s. 24; I. T. Berend, G. Ránki, Economic Development in East-Central Europe in the 19th and 20th Centuries, Columbia University Press 1974, s. 182.

4. R. J. Kerner, At the Peace Conference, [w:] J. Opočenský, ed., Edward Beneš. Essays and Reflections Presented on the Occasion of His Sixtieth Birthday, London 1945, s. 79.

5. Szerzej na ten temat piszę w książce: Czechosłowacja w polityce Stanów Zjednoczonych w latach 1918-1933, Białystok 1996.

6. „New York Times” (NYT), 19 lutego 1920, s. 12; NYT, 15 marca 1920, 16:1; NYT, 8 stycznia 1921, 8:1; NYT, 16 kwietnia 1922, VII, 3:1; NYT, 4 listopada 1923, V, s. 1.

7. CzR, lipiec 1921, s. 195; CzR, sierpień 1921, s. 231, 233; CzR, wrzesień 1921, s. 273.

8. "Current History” 1921, v. 5, s. 835-845.

9. CzR, lipiec 1921, s. 195, 199; CzR, sierpień 1921, s. 231; CzR, październik 1921, s. 294.

10. Hoover institution (HI), Goodyear Anson Conger Papers, Box 2, f. 14, Memoirs.

11. NYT, 1 czerwca 1920, 17:6.

12. NYT, 30 stycznia 1921, II, 1:2.

13. NYT, 21 kwietnia 1921, 4:2; CzR, czerwiec 1921, s. 185.

14. Lauinger Library (LL), Richard Crane Papers (RCP), Box 5, f. 26, Diary, 1920-1921.

15. J. Cisar̆, F. Pokorny, P. Selver, The Czechoslovak Republic. A Survey of Its History and Geography, Its Political and Cultural Organization, and Its Economic Resources, Prague: Orbis 1922; J. Gruber, ed., Czechoslovakia. A Survey of Economic and Social Conditions, translated by A. Brož, S. V. Klima and J. J. Král, New York 1924.

16. A. Broż, The First Year of the Czecho-Slovak Republic, London 1920; tenże, Three Years of the Czechoslovak Republic. A Survey of Its Progress and Achievements, Prague 1921.

17. NYT, 30 stycznia 1921, II, 1:2. Wiele na ten temat pisał „The Czechoslovak Review”, licząc na aktywizację stosunków USA także z Czechosłowacją.

18. Szerzej na ten temat pisałam w pracy: Polska w europejskiej polityce Stanów Zjednoczonych w okresie prezydentury Herberta C. Hoovera (1929-1933), Białystok 1991.

19. National Archives (NA), Record Group (RG) 165, Box 254. Raport attaché wojskowego z 2 stycznia 1920.

20. Státní ústřední archiv (SÚA), Výstřižkový archiv, 816, 1920.

21. NA, RG 151, 722.1 Fairs - Czechoslovakia.

22. LL, RCP, Box 6, f. 15, Letters of congratulations 1919. Pismo gratulacyjne z 19 kwietnia 1919 dyrektora War Trade Intelligence.

23. CzR, maj 1919, s. 142.

24. CzR, maj 1919, s. 142; B. Lockhart, Jan Masaryk. A Personal Memoir, New York 1951, s. 13.

25. Koneksje rodzinne Masaryków i Crane'ów zostały zacieśnione. W 1922 brat posła, John Crane był stypendystą w Pradze i pełnił obowiązki prywatnego sekretarza prezydenta Masaryka. John Crane był autorem The Little Entente, New York 1931. Siostrę posła amerykańskiego w Pradze, Franches Crane, poślubił w grudniu 1924 syn prezydenta, Jan Masaryk. Ich kilkuletnie pożycie małżeńskie zakończyło się rozwodem.

26. J. Kose, America in Czechoslovakia, Prague 1922, s. 7.

27. HI, Hugh Gibson Papers (HGP), Box 17, f. William R. Castle Jr., 1920. Stwierdził on też, że: „The judicious and farseeing American minister in Prague never thinks of scrutinizing 
the statements made by Benes and other officials of the Government, but accepts all their propaganda at absolutely face value".

28. NA, RG 165, Box 254. Raporty z 1920.

29. NA, RG 165, Box 1539.

30. LL, RCP, Box 6, f. 18, Departure from Prague.

31. NA, American Legation, Prague (ALP), Correspondence, Crane (CC), 1921, v. IX, 800.1.-841.5 .

32. LL, RCP, Box 7-9.

33. NYT, 7 marca 1920, 14:2; NYT, 26 kwietnia 1920, 21:3 NYT, 28 listopada 1920, 12:3.

34. CzR, styczeń 1919, s. 23; CzR, kwiecień 1919, s. 102.

35. CzR, sierpień 1919, s. 242-243.

36. NYT, 26 kwietnia 1920, 21:3.

37. NYT, 28 listopada 1920, 12:3.

38. CzR, maj 1921, s. 153.

39. Register of the State Department (RSD), 1922, s. 259; RSD, 1924, s. 261.

40. RSD, 1927, s. 275.

41. Jest to interesujący temat badawczy, który nie znalazł dotychczas należytego opracowania.

42. Archiv Ministerstva zahraničních věci (AMZV), Vyslanectvi Československe republiky ve Washingtonu (VCR), 1921. Raporty dyplomatyczne z 1921.

43. Masarykúv archiv (MA), Tomáš Garrigue Masaryk Fond (TGMF), Zahraniči - USA, Box 26. Pismo Caldwella do prezydenta Masaryka z 29 października 1919.

44. MA, Jan Masaryk Fond (JMF), Box 1. Korespondencja z 1919-1920.

45. R. J. Caldwell, The Economic Situation in Czechoslovakia in 1920, Washington 1920.

46. MA, TGMF, Box 26. 30 grudnia 1920 poseł Štěpánek pisał do prezydenta Masaryka o głośnym artykule Czechoslovakia's Situation More Favourable Than Other States, który był szeroko komentowany w amerykańskiej prasie i miał w niej liczne przedruki.

47. NYT, 7 marca 1920, 14:2; NYT, 8 kwietnia 1921, 3:1. John Finley o prezydencie Masaryku pisał, że sprawował on rządy „z wiedzą historyka, doświadczeniem nauczyciela, temperamentem filozofa i wizja proroka" (NYT, 8 czerwca 1921, 3:1). 